\title{
The effects of dietary hot pepper Capsicum annuum waste powder supplementation on egg production traits of Japanese quail layers
}

\begin{abstract}
Gökhan Filik $^{1^{*}}$ (D) Ayşe Gül Filik ${ }^{1}$ (D) Aydın Altop ${ }^{2}$ (D)
${ }^{1}$ Agricultural Biotechnology Department, Agriculture Faculty, Kırşehir Ahi Evran University, Kırşehir, 40100, Turkey. E-mail: gfilik@ahievran.edu.tr. ${ }^{*}$ Corresponding author.

${ }^{2}$ Animal Science Department, Agriculture Faculty, Ondokuz Mayıs University, Samsun, 55139, Turkey.

ABSTRACT: This study was conducted to evaluate the effects of different levels of dietary hot pepper (Capsicum annuum L.) waste supplementation on egg production performance and quality in Japanese quail hens (Coturnix coturnix japonica). A total of 192, seven-weekold Japanese quail layers were divided into 4 treatment groups of similar mean weight ( $304 \pm 0.5 \mathrm{~g})_{2}$ each comprising 12 subgroups (including 1 male and 3 females). Treatment birds were fed on experimental basal layer diet supplemented with 1, 2 or $4 \mathrm{~g}$ hot pepper waste powder (HPWP) per $\mathrm{kg}$ diet. The laying performance was determined by recording feed intake, egg weight, daily egg production, and biweekly egg quality. Results showed that HPWP supplementation to layer diet did not have any significant $(P>0.05)$ effects on body weight and feed conversion ratio, while it had significant effects on feed intake $(P<0.01)$, and laying egg weight, average egg weight, total egg yield (P<0.05). A $2 \mathrm{~g} H P W P$ supplementation resulted in the highest total egg yield $(P<0.05)$ with quadratic effects on egg shape index $(P<0.05)$ and albumen $p H(P<0.01)$. According to the values in the study, the egg shape index of $2 \mathrm{~g} H P W P$ group was circular and; therefore, attractive to consumers. We highly recommend the non-economic value of $2 \mathrm{~g} / \mathrm{kg}$ supplementation of hot pepper waste powder, especially for egg production. To conclude, HPWP can be used for quail layer diets due to its beneficial effects on egg quality since it is an economic and easy agricultural by-product obtained from red pepper paste industry waste.
\end{abstract}

Key words: albumen $\mathrm{pH}$, by-product, egg quality, hot pepper, Japanese quail layers.

Efeitos da suplementação de pó de Capsicum annuum na dieta sobre a produção de ovos de codornas japonesas

RESUMO: Este estudo foi conduzido para avaliar os efeitos de diferentes níveis de suplementação de resíduos de pimenta na dieta (Capsicum annuum L.), no desempenho e na qualidade da produção de ovos em codornas japonesas (Coturnix coturnix japonica). Um total de 192 codornas japonesas com sete semanas de idade foram alocadas em 4 grupos com peso médio semelhante (304 $\pm 0.5 \mathrm{~g})$, cada um compreendendo 12 subgrupos (incluindo 1 macho e 3 fêmeas). As aves tratadas foram alimentadas com dieta experimental basal suplementada com 1 , 2 ou $4 \mathrm{~g}$ de pimenta em pó $(H P W P)$ por $\mathrm{kg}$ de dieta. O desempenho da postura foi determinado pelo registro da ingestão de ração, peso dos ovos, produção diária de ovos e qualidade quinzenal dos ovos. Os resultados mostraram que a suplementação de HPWP à dieta não teve efeitos significativos $(P>0,05)$ no peso corporal e na taxa de conversão alimentar, enquanto teve efeitos significativos no consumo de ração $(P<0,01)$ e no peso do ovo em postura, peso médio do ovo, produção total de ovos $(P<0,05)$. Uma suplementação de 2 g de HPWP resultou na maior produção total de ovos $(P<0,05)$ com efeitos quadráticos no indice de forma dos ovos $(P<0,05)$ e no $p H$ do albumen $(P<0,01)$. De acordo com os valores do estudo, o índice de forma dos ovos de $2 \mathrm{~g}$ do grupo HPWP era circular e, portanto, atraente para os consumidores. É altamente recomendável o valor não-econômico de $2 \mathrm{~g} / \mathrm{kg}$ de suplementação de pó de pimenta, especialmente para a produção de ovos. Para concluir, a HPWP pode ser usada para dietas de codorna devido aos seus efeitos benéficos na qualidade dos ovos, uma vez que é um subproduto agrícola obtido a partir de resíduos da indústria de pasta de pimenta vermelha de maneira econômica e fácil.

Palavras-chave: $p H$ do albume, subproduto, qualidade dos ovos, pimenta, camadas de codornas japonesas.

\section{INTRODUCTION}

Egg is the richest and cheapest animal protein resource for human health or food. For this reason, its production has been increased in worldwide scale. Consumers generally have chicken, turkey, goose, duck and quail eggs. Quail eggs are gaining the attention of consumers because of their rich nutrient value. For example; A 9-gram quail egg has $14.22 \mathrm{kcal} \mathrm{ME}, 1.17 \mathrm{~g}$ protein, $5.76 \mathrm{mg}$ $\mathrm{Ca}, 5.94 \mu \mathrm{g}$ folate (dietary folate equivalent), 75.96 mg cholesterol (USDA, 2018). Although, Japanese 
quails play an important part in egg production as layer hens, there have been no documents about the production of quail egg quantities. In 2013, the number of eggs produced in the world increased from 1.285.108.506 to 1.378.152.798 trillion in 2018, an increase of $6.75 \%$ (FAO, 2020). Nevertheless, an increasing amount of non-conventional or natural additives have been needed to meet this growing production. This growing demand increases the costs of raw feed materials.

While antibiotics are used for growth regulation and health protection in poultry nutrition, there is increasing human resistance to antibiotics (Castanon, 2007). For this reason, the feed industry has not used antibiotics anymore, especially in the EU, in feed formulations for poultry and researchers are searching for new additives in feed formulation materials as an alternative to antibiotics. Consequently, researchers have focused on using antibiotic growth promoters (AGPs): probiotics, prebiotics, synbiotics, organic acids, enzymes, phytogenics, hyperimmune egg yolk antibodies, antimicrobial peptides, bacteriophages, clay and metals (Gadde et al. 2017). Phytogenics use a wide range of plants or extracts like thyme, cinnamon, rosemary, cumin and/or expensive spices like garlic, black pepper, red pepper, etc. (CHOWDHURY and SMITH, 2002; RADWAN NADIA et al. 2008; AL-HARTHI et al. 2009; TORKI et al. 2015). Red pepper (Capsicum annuит L.) is used for degassing the intestine, accelerating the removal of metabolic products, increasing the body temperature, facilitating digestion, constructive vasoconstriction, reducing meat and blood cholesterol and reducing abdominal fat accumulation (MAOKA et al. 2001, ERDOST et al. 2006, HOLST et al. 2010, EL-DEEK et al. 2012, SHAHVERDI et al. 2013, PUVAĆA et al. 2014, PUVAĆA et al. 2015). However, there has not been any study on the use of red pepper waste (byproducts) in poultry nutrition as a feed or feed additive. For this reason, we conducted this study to investigate whether red pepper paste industry waste would affect the laying performance and egg quality of Japanese quail layers.

\section{MATERIALS AND METHOD}

In this experiment, healthy and wellperforming quail layers (Coturnix coturnix japonica) were used. A total of 192, seven-week-old Japanese quail layers were divided into 4 treatment groups of similar mean weight, comprising 12 subgroups with 1 male and 3 females in each. To determine the chemical content of hot pepper waste powder (HPWP) and basal diet, samples were dried in a ventilated drying oven at $65{ }^{\circ} \mathrm{C}$ for 48 hours. The dried sample was ground (Ultra-Centrifugal Mill ZM 200- Retsch) in a $1 \mathrm{~mm}$ sieve grinder before analysis. The organic matter or moisture (OM: M method 934.01), crude protein (CP: method 984.13), crude fiber (CF: method 978.10), ether extract (EE: method 920.39), ash (ash: method 942.05 (4.1.10)), Acid Detergent Fiber (ADF: BFM62) and Neutral Detergent Fiber (NDF: BFM119) contents of the hot pepper waste powder and animal feeds were determined according to the AOAC procedure (2006) (Tables 1 and 2).

The birds were fed on a standard layer diet each $\mathrm{kg}$ containing $170 \mathrm{~g}$ crude protein, $38 \mathrm{~g}$ calcium and phosphorus, and $2800 \mathrm{Kcal}$ ME. The HPWP was acquired from a private red pepper paste factory in Şanlıurfa, Turkey. Treatment birds were fed on the experimental basal layer diet supplemented with 1, 2 or $4 \mathrm{~g}$ HPWP per $\mathrm{kg}$ diet. This study lasted for 8 weeks.

Birds housed in cages were subjected to $16: 8$ hours, light/dark photoperiod. Eggs were collected twice a day, at 9 am and $3 \mathrm{pm}$. Feed was given ad libitum and water was continuously available from nipple drinkers throughout the day. Laying performance was determined daily by measuring the change in body weight (BW), feed intake (FI), egg mass, feed conversion ratio (FCR) (feed intake: egg

Table 1 - Chemical content of the hot pepper waste powder.

\begin{tabular}{lc}
\hline Ingredients (Dry matter basis) & $(\%)$ \\
\hline Organic Matter & 91.63 \\
Crude Protein & 16.35 \\
Crude Fiber & 30.82 \\
Ether Extract & 11.28 \\
Ash & 8.82 \\
\hline
\end{tabular}


Table 2 - Chemical content and nutrient value of the experimental basal diet.

\begin{tabular}{|c|c|}
\hline Ingredients $^{1,2}$ & Experimental Basal Diet $(\mathrm{g} / \mathrm{kg})$ \\
\hline Yellow corn & 537.739 \\
\hline Soy bean meal $46 \% \mathrm{CP}$ & 170.084 \\
\hline Limestone & 96.441 \\
\hline Sunflower meal $36 \%$ CP & 91.110 \\
\hline Barley $11 \%$ CP & 30.000 \\
\hline Soy bean Oil & 28.312 \\
\hline Wheat bran $14 \% \mathrm{CP}$ & 10.000 \\
\hline D-L Methionine $99 \%$ & 8.139 \\
\hline MCP 22,7 (TIMAB) & 5.792 \\
\hline DDGS $27 \% \mathrm{CP}$ & 5.000 \\
\hline FFS 34 & 5.000 \\
\hline Chicken feather flour 56 & 5.000 \\
\hline Salt & 2.756 \\
\hline Ekomix VM egg & 2.000 \\
\hline Sodium bicarbonat & 1.025 \\
\hline Rovabio MAX & 1.000 \\
\hline Calsporin & 0.600 \\
\hline Chemical Composition $^{3}$ & (g) \\
\hline $\mathrm{ME}, \mathrm{kcal} / \mathrm{kg}$ & 2800.000 \\
\hline Crude Protein 15.3 & 170.00 \\
\hline Calcium 3.8 & 38.00 \\
\hline Available Phosphorus 0.35 & 38.00 \\
\hline Lysine 0.75 & 6.85 \\
\hline Methionine 0.35 & 10.54 \\
\hline Threonine 0.58 & 5.27 \\
\hline Tryptophan 0.19 & 2.00 \\
\hline
\end{tabular}

${ }^{1}$ Provided per kilogram of diet: retinyl acetate, $9012 \mathrm{IU}$; cholecalciferol, $1500 \mathrm{IU}$; DL- $\alpha$-tocopheryl acetate, $7.5 \mathrm{IU}$; thiamin, $0.6 \mathrm{mg}$; riboflavin, $4.8 \mathrm{mg}$; pyridoxine hydrochloride, $1.5 \mathrm{mg}$; cyanocobalamin, $0.009 \mathrm{mg}$; calcium-D-pantothenate, $7.5 \mathrm{mg}$; folic acid, $0.15 \mathrm{mg}$; niacin, $20 \mathrm{mg}$.

${ }^{2}$ Provided per kilogram of diet: copper $\left(\mathrm{CuSO}_{4} * 5 \mathrm{H}_{2} \mathrm{O}\right), 6 \mathrm{mg}$; iron $\left(\mathrm{FeSO}_{4}{ }^{*} \mathrm{H}_{2} \mathrm{O}\right), 60 \mathrm{mg}$; zinc $\left(\mathrm{ZnSO}_{4}{ }^{*} \mathrm{H}_{2} \mathrm{O}\right), 80 \mathrm{mg}$; manganese $\left(\mathrm{MnSO}_{4}{ }^{*} \mathrm{H}_{2} \mathrm{O}\right), 60 \mathrm{mg}$; selenium $\left(\mathrm{NaSeO}_{3}\right), 0.3 \mathrm{mg}$; iodine $(\mathrm{KI}), 0.35 \mathrm{mg}$.

${ }^{3}$ The value of crude protein was analyzed and the value of metabolizable energy (ME) and other values were calculated.

mass) and egg production (hen per day). Egg quality was estimated by measuring the egg-shape index (width*100/length), shell weight, shell thickness, egg weight, yolk weight, albumen weight, albumen height, yolk index (weight/height), Haugh unit, breaking resistance (using a Brookfield, CT3 Texture Analyzer, Probe No: TA24) and yolk color $\left(L^{*}, a^{*}, b^{*}\right.$, chroma and $h^{o}$; using a Konica Minolta, CR-410 Chroma Meter) of each egg obtained on the third day of every week. Shell samples from the top, middle, and bottom of the egg were measured for thickness using a micrometer and the mean was calculated before statistical analysis. The data obtained in the experiment were analyzed using General Linear Models (GLM) and SAS orthogonal polynomials (1997). Linear, quadratic and cubic effects were determined by orthogonal polynomial contrast (DÜZGÜNEŞ et al. 1987).

\section{RESULTS AND DISCUSSION}

The performance parameters: change in body weight, daily feed intake (g per bird) and feed conversion ratio ( $\mathrm{g}$ feed $/ \mathrm{g}$ egg) results are given in table 3 . Results for the change in body weight effects of HPWP supplementation showed that the group subjected to $2 \mathrm{~g} / \mathrm{kg}$ of HPWP supplementation recorded the least change in BW. Although, FI was affected $(\mathrm{P}=0.000)$, but the feed conversion ratio was not affected by supplementation 
Table 3 - The effects of different levels of hot pepper waste powder supplementation on body weight gain, feed intake and feed conversion ratio of Japanese quail layers.

\begin{tabular}{|c|c|c|c|c|c|c|c|c|c|}
\hline \multirow[t]{2}{*}{ Parameters } & \multicolumn{4}{|c|}{ 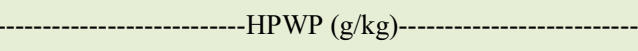 } & \multirow[t]{2}{*}{ SED } & \multirow[t]{2}{*}{$\mathrm{P}$} & \multicolumn{3}{|c|}{------------Effects ${ }^{\ddagger}$----------- } \\
\hline & 0 & 1 & 2 & 4 & & & $\mathrm{~L}$ & Q & $\mathrm{C}$ \\
\hline Initial BW (g/ bird) & 310.3 & 310.3 & 310.5 & 310.1 & 2.28 & 1.000 & 0.975 & 0.968 & 0.966 \\
\hline Final BW (g/ bird) & 334.8 & 333.0 & 331.1 & 334.6 & 2.67 & 0.957 & 0.924 & 0.62 & 0.8203 \\
\hline Change in BW ( $\mathrm{g} /$ bird) & 24.5 & 21.9 & 20.6 & 24.6 & 3.33 & 0.966 & 0.969 & 0.623 & 0.899 \\
\hline FI (g/ day per bird) & $34.2^{\mathrm{a}}$ & $32.5^{b}$ & $35.2^{\mathrm{a}}$ & $34.5^{\mathrm{a}}$ & 0.17 & 0.000 & 0.029 & 0.143 & 0.000 \\
\hline FCR & 3.2 & 3.4 & 3.1 & 3.4 & 0.07 & 0.305 & 0.895 & 0.600 & 0.071 \\
\hline
\end{tabular}

${ }^{\mathrm{a}-\mathrm{b}}$ Means in the same row bearing different superscripts differ significantly. BW: Body Weight, BWG: Body Weight Gain, FI: Feed Intake, FCR: Feed Conversion Ratio (g feed /g egg).

SED: Standard Error of the Difference between the means.

${ }^{\sharp}$ :Effects; L: linear, Q: quadratic, C: cubic.

with HPWP $(\mathrm{P}>0.05)$. As a result, FI was affected by HPWP supplementation $(\mathrm{P}=0.000)$ but the change in $\mathrm{BW}$ was not $(\mathrm{P}>0.05)$. Conversely, dietary supplemental HPWP did not affect the health status of animals negatively.

The egg production results are given in table 4 . The total egg weight and average egg weight (g/ 3 birds/ 56 days) were increased $(\mathrm{P}<0.05)$ in $2 \mathrm{~g} / \mathrm{kg}$ HPWP supplemented group. Hot pepper (Capsicum annuum L.) reduced blood and meat cholesterol, and the accumulation of abdominal fat (EL-DEEK et al. 2012; SHAHVERDI et al. 2013; PUVAĆA et al. 2014). At the same time, the carcass fat concentration showed a synergistic relationship between calcium, phosphorus and Vitamin D. The 2 $\mathrm{g} / \mathrm{kg}$ HPWP supplementation hens used their body reserves to lay (reproduce) more eggs $(\mathrm{P}<0.05)$. For this reason, $2 \mathrm{~g}$ hot pepper waste powder decreased body weight since the body reserves, most likely, have been used for egg production compared to other experimental groups.

Egg quality results are given in table 5. Results, for egg quality revealed that HPWP supplementation affected egg shape index. It is well known that the egg shape index value is one of the significant quality criteria in egg marketing. The commercial poultry egg shape index should be between 72 and 76. If it is lower than 72 , this means that the egg shape is sharp, while a value higher than 76 means it is round (ŞENKÖYLÜ, 2001). However, the quail egg shape index should be between 76 and 79 (ÇOPUR et al. 2010). Generally, customers prefer to buy big or heavy eggs, but the results from the egg shape index showed that HPWP supplementation had a significant quadratic effect $(\mathrm{P}<0.05)$. According to the values in this study, the egg shape index indicated round eggs that are preferable for consumers.

Breaking resistance showed a linear increase for the HPWP supplementation groups ( $\mathrm{P}>0.05)$, but the control group was better than supplemental groups. We can conclude that the reason for the decline of the shell resistance in the HPWP supplementation group, compared to the control group, was fat burning in the body. Vitamin D, Ca and $\mathrm{P}$ are vital for the development of the eggshell and they are transferred by fat in the body. As the HPWP supplementation accelerates fat burning, this prevents the transference of the required quantities of Vitamin D, calcium and phosphorus that are so essential for the development of the eggshell in the body. Breaking resistance in the treatment groups decreased in magnitude compared to the control groups.

Average egg thickness was changed by HPWP supplementation; because of this, results showed that the egg shape index is better at $2 \mathrm{~g} / \mathrm{kg}$ of HPWP compared to other groups. The HPWP supplementation improved the $a^{*}(\mathrm{P}<0.05)$ and $b^{*}$ values so that the yolk's yellow and red color was increased by HPWP supplementation doses. These findings agree with those of Li et al. (2012) that $a^{*}$ and $b^{*}$ values showed a "reddish" yolk color.

Hot pepper waste powder supplementation has antimicrobial activity and improves reproduction performance in laying hens. Zeweil et al. (2011) observed that a $1.5 \%$ hot pepper supplementation in the diet had inhibitory 
Table 4 - The effects of different levels of hot pepper waste powder on egg weight and yields of Japanese quail layers.

\begin{tabular}{|c|c|c|c|c|c|c|c|c|c|}
\hline \multirow{2}{*}{$\begin{array}{l}\text { Parameters } \\
\text { Average of egg weight (g) }\end{array}$} & \multicolumn{4}{|c|}{----------------'HPWP (g/kg)-------------- } & \multirow[t]{2}{*}{ SED } & \multirow[t]{2}{*}{$\mathrm{P}$} & \multicolumn{3}{|c|}{--------------Effects ${ }^{¥}$------------ } \\
\hline & 0 & 1 & 2 & 4 & & & $\mathrm{~L}$ & Q & $\mathrm{C}$ \\
\hline Week 1 & $11.3^{\mathrm{a}}$ & $11.3^{\mathrm{a}}$ & $11.2^{\mathrm{a}}$ & $6.4^{\mathrm{b}}$ & 0.07 & 0.000 & 0.000 & 0.000 & 0.000 \\
\hline Week 2 & 13.00 & 12.6 & 12.5 & 12.7 & 0.10 & 0.366 & 0.342 & 0.135 & 0.923 \\
\hline Week 3 & $13.7^{\mathrm{a}}$ & $13.1^{\mathrm{ab}}$ & $13.1^{\mathrm{ab}}$ & $12.9^{\mathrm{b}}$ & 0.11 & 0.085 & 0.026 & 0.289 & 0.455 \\
\hline Week 4 & $13.6^{\mathrm{a}}$ & $13.1^{\mathrm{ab}}$ & $13.2^{\mathrm{ab}}$ & $12.9^{\mathrm{b}}$ & 0.11 & 0.179 & 0.052 & 0.595 & 0.363 \\
\hline Week 5 & 13.7 & 13.3 & 13.3 & 13.2 & 0.10 & 0.337 & 0.125 & 0.426 & 0.537 \\
\hline Week 6 & $12.4^{\mathrm{b}}$ & $13.5^{\mathrm{a}}$ & $13.5^{\mathrm{a}}$ & $13.4^{\mathrm{a}}$ & 0.14 & 0.018 & 0.014 & 0.027 & 0.469 \\
\hline Week 7 & 13.8 & 13.6 & 13.7 & 13.8 & 0.11 & 0.814 & 0.876 & 0.347 & 0.885 \\
\hline Week 8 & 13.8 & 13.5 & 13.6 & 13.6 & 0.10 & 0.891 & 0.806 & 0.551 & 0.656 \\
\hline \multicolumn{10}{|c|}{----1- } \\
\hline Week 1 & $175.4^{\mathrm{ab}}$ & $181.4^{\mathrm{a}}$ & $190.4^{\mathrm{a}}$ & $154.3^{\mathrm{b}}$ & 4.53 & 0.044 & 0.181 & 0.023 & 0.237 \\
\hline Week 2 & $225.1^{\mathrm{ab}}$ & $209.6^{\mathrm{ab}}$ & $246.7^{\mathrm{a}}$ & $200.7^{\mathrm{b}}$ & 6.58 & 0.081 & 0.538 & 0.248 & 0.025 \\
\hline Week 3 & $232.5^{\mathrm{ab}}$ & $201.1^{\mathrm{b}}$ & $244.3^{\mathrm{a}}$ & $212.7^{\mathrm{ab}}$ & 6.11 & 0.066 & 0.764 & 0.995 & 0.008 \\
\hline Week 4 & $242.7^{\mathrm{ab}}$ & $212.8^{\mathrm{b}}$ & $261.2^{\mathrm{a}}$ & $218.3^{\mathrm{b}}$ & 6.17 & 0.027 & 0.654 & 0.597 & 0.003 \\
\hline Week 5 & $246.0^{\mathrm{a}}$ & $207.9^{\mathrm{b}}$ & $258.1^{\mathrm{a}}$ & $226.7^{\mathrm{ab}}$ & 5.74 & 0.018 & 0.878 & 0.771 & 0.002 \\
\hline Week 6 & $236.4^{\mathrm{ab}}$ & $216.3^{b}$ & $279.6^{\mathrm{a}}$ & $250.3^{\mathrm{ab}}$ & 7.44 & 0.030 & 0.119 & 0.757 & 0.011 \\
\hline Week 7 & 245.25 & 220.67 & 260.75 & 240.5 & 6.92 & 0.274 & 0.688 & 0.880 & 0.057 \\
\hline Week 8 & $232.8^{\mathrm{ab}}$ & $208.8^{\mathrm{b}}$ & $232.6^{\mathrm{ab}}$ & $252.9^{\mathrm{a}}$ & 7.04 & 0.187 & 0.183 & 0.120 & 0.417 \\
\hline Morning (9 AM) & $1381.4^{\mathrm{ab}}$ & $1202.8^{\mathrm{b}}$ & $1425.6^{\mathrm{a}}$ & $1300.7^{\mathrm{ab}}$ & 31.93 & 0.080 & 0.945 & 0.673 & 0.011 \\
\hline Afternoon (3 PM) & 450.6 & 518.4 & 509.7 & 463.3 & 21.28 & 0.605 & 0.876 & 0.189 & 0.837 \\
\hline Laying egg weight (g) & $10.9^{\mathrm{ab}}$ & $9.9^{\mathrm{b}}$ & $11.8^{\mathrm{a}}$ & $10.5^{\mathrm{ab}}$ & 0.23 & 0.040 & 0.827 & 0.796 & 0.005 \\
\hline Egg production $(\%)$ & $82.7^{\mathrm{ab}}$ & $76.0^{\mathrm{b}}$ & $90.2^{\mathrm{a}}$ & $86.5^{\mathrm{a}}$ & 1.66 & 0.028 & 0.093 & 0.656 & 0.012 \\
\hline Average egg weight ( $\mathrm{g} / 3$ birds 56 days) & $32.8^{\mathrm{ab}}$ & $29.6^{\mathrm{b}}$ & $35.2^{\mathrm{a}}$ & $31.4^{\mathrm{ab}}$ & 0.69 & 0.040 & 0.827 & 0.796 & 0.005 \\
\hline Total egg yield ( $\mathrm{g} / 3$ birds/56 days) & $1836.1^{\mathrm{ab}}$ & $1658.6^{\mathrm{b}}$ & $1973.5^{\mathrm{a}}$ & $1756.3^{\mathrm{ab}}$ & 38.27 & 0.040 & 0.827 & 0.796 & 0.005 \\
\hline \multicolumn{10}{|c|}{ - } \\
\hline Morning (9AM) & $105.4^{\mathrm{ab}}$ & $93.8^{\mathrm{b}}$ & $110.8^{\mathrm{a}}$ & $110.7^{\mathrm{a}}$ & 2.34 & 0.041 & 0.121 & 0.217 & 0.032 \\
\hline Afternoon (3PM) & 34.0 & 38.6 & 37.7 & 35.5 & 1.53 & 0.716 & 0.794 & 0.275 & 0.753 \\
\hline Pieces ( 3 birds/56 days) & $139.0^{\mathrm{ab}}$ & $127.8^{\mathrm{b}}$ & $151.6^{\mathrm{a}}$ & $145.3^{\mathrm{a}}$ & 2.79 & 0.028 & 0.093 & 0.656 & 0.012 \\
\hline
\end{tabular}

${ }^{a-b}$ Means in the same row bearing different superscripts differ significantly.

SED: Standard Error of the Difference between the means.

*:Effects; L: linear, Q: quadratic, C: cubic.

effects on the E. coli, Salmonella and Streptococci count. Normally, the albumen $\mathrm{pH}$ value is between 7.6 and 9.5 in avian eggs and negatively affected by the microorganism population (GUYOT et al. 2013). In this study, albumen $\mathrm{pH}$ showed that HPWP supplementation had a significant linear effect $(\mathrm{P}<0.01)$. The reason for the increase in the $\mathrm{pH}$ of the hot pepper waste powder supplementation groups compared to the control group was due to the antimicrobial activity of hot pepper. Supplementation of the basal layer diet with hot pepper waste powder doses significantly improved albumen $\mathrm{pH}$. The rise in $\mathrm{CO}_{2}$ within the egg air space can be explained by the increased microorganism activities; however, high $\mathrm{pH}$ values inhibited and limited $\mathrm{CO}_{2}$ production in the egg. The $\mathrm{pH}$ value is a very important parameter in the shelf life of eggs during storage and transporting for retailers.

\section{CONCLUSION}

The HPWP used in this study increased egg yield and egg weight at $2 \mathrm{~g} / \mathrm{kg}$ level without affecting the health status of birds, their feed intake and body weight changes. However, this level tended to increase egg quality for shape index, albumen weight, albumen $\mathrm{pH}$ and color. Above all, HPWP can be obtained easily and economically from red pepper paste industry waste. Also, this usage in poultry nutrition can contribute to the prevention of environmental pollution. For this reason, HPWP can be used for quail layer diets due to its beneficial effects on egg quality and albumen $\mathrm{pH}$. 
Table 5 - The effects of different levels of hot pepper waste powder on the egg quality parameters of Japanese quail layers.

\begin{tabular}{|c|c|c|c|c|c|c|c|c|c|}
\hline \multirow[t]{2}{*}{ Parameters } & \multicolumn{4}{|c|}{ 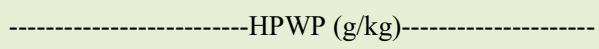 } & \multirow[t]{2}{*}{ SED } & \multirow[t]{2}{*}{$\mathrm{P}$} & \multicolumn{3}{|c|}{---------Effects ${ }^{*}--------$} \\
\hline & 0 & 1 & 2 & 4 & & & $\mathrm{~L}$ & Q & $\mathrm{C}$ \\
\hline Egg weight (g) & 13.1 & 13.1 & 13.0 & 13.2 & 0.07 & 0.849 & 0.805 & 0.460 & 0.669 \\
\hline Shell weight (g) & $1.5^{\mathrm{ab}}$ & $1.4^{\mathrm{b}}$ & $1.4^{\mathrm{b}}$ & $1.5^{\mathrm{a}}$ & 0.01 & 0.055 & 0.507 & 0.009 & 0.532 \\
\hline Shell weight (\%) & $11.1^{\mathrm{ab}}$ & $10.8^{\mathrm{b}}$ & $10.7^{b}$ & $11.2^{\mathrm{a}}$ & 0.07 & 0.032 & 0.522 & 0.004 & 0.603 \\
\hline Shape index $(\%)$ & 79.1 & 80.1 & 80.3 & 79.6 & 0.20 & 0.145 & 0.316 & 0.037 & 0.942 \\
\hline Width (mm) & 26.6 & 26.7 & 26.7 & 26.7 & 0.06 & 0.829 & 0.463 & 0.586 & 0.850 \\
\hline Length (mm) & 33.6 & 33.3 & 33.3 & 33.6 & 0.09 & 0.461 & 0.716 & 0.122 & 0.933 \\
\hline Egg shell top (mm) & 0.2 & 0.2 & 0.2 & 0.2 & 0.01 & 0.194 & 0.670 & 0.421 & 0.050 \\
\hline Egg shell mid (mm) & $0.2^{\mathrm{a}}$ & $0.2^{\mathrm{ab}}$ & $0.2^{\mathrm{ab}}$ & $0.2^{\mathrm{b}}$ & 0.01 & 0.104 & 0.042 & 0.259 & 0.362 \\
\hline Egg shell bottom (mm) & 0.2 & 0.2 & 0.2 & 0.2 & 0.00 & 0.354 & 0.223 & 1.000 & 0.185 \\
\hline Average thickness (mm) & $0.2^{\mathrm{a}}$ & $0.2^{\mathrm{b}}$ & $0.2^{\mathrm{ab}}$ & $0.2^{\mathrm{b}}$ & 0.00 & 0.091 & 0.110 & 0.426 & 0.070 \\
\hline Albumen weight (g) & 7.7 & 7.7 & 7.7 & 7.8 & 0.05 & 0.973 & 0.757 & 0.803 & 0.801 \\
\hline Albumen weight (\%) & 58.7 & 58.9 & 59.1 & 58.8 & 0.16 & 0.823 & 0.805 & 0.379 & 0.803 \\
\hline Albumen height (mm) & 5.5 & 5.6 & 5.4 & 5.4 & 0.05 & 0.562 & 0.409 & 0.548 & 0.319 \\
\hline Albumen width (mm) & 40.7 & 40.5 & 40.1 & 39.4 & 0.26 & 0.353 & 0.091 & 0.548 & 0.922 \\
\hline Albumen length (mm) & 51.9 & 51.6 & 51.2 & 51.7 & 0.34 & 0.882 & 0.733 & 0.553 & 0.668 \\
\hline Albumen $\mathrm{pH}$ & $8.8^{\mathrm{b}}$ & $9.1^{\mathrm{a}}$ & $9.2^{\mathrm{a}}$ & $9.2^{\mathrm{a}}$ & 0.04 & 0.003 & 0.001 & 0.048 & 0.511 \\
\hline Albumen index (\%) & 7.6 & 7.8 & 7.6 & 7.6 & 0.08 & 0.766 & 0.743 & 0.455 & 0.494 \\
\hline Yolk weight (g) & 4.00 & 4.00 & 3.9 & 4.00 & 0.03 & 0.968 & 0.834 & 0.791 & 0.709 \\
\hline Yolk weight (\%) & 30.3 & 30.3 & 30.2 & 30.0 & 0.16 & 0.920 & 0.588 & 0.659 & 0.986 \\
\hline Yolk height (mm) & $12.4^{\mathrm{b}}$ & $12.9^{\mathrm{a}}$ & $12.8^{\mathrm{ab}}$ & $12.8^{\mathrm{ab}}$ & 0.07 & 0.122 & 0.220 & 0.094 & 0.210 \\
\hline Yolk width (mm) & 24.6 & 25.2 & 24.9 & 24.8 & 0.13 & 0.417 & 0.832 & 0.218 & 0.262 \\
\hline Yolk index (\%) & 50.6 & 51.2 & 51.3 & 51.4 & 0.26 & 0.646 & 0.266 & 0.561 & 0.808 \\
\hline$L^{*}$ & 69.7 & 69.6 & 70.8 & 70.7 & 0.33 & 0.374 & 0.115 & 0.919 & 0.443 \\
\hline$a^{*}$ & $11.0^{\mathrm{b}}$ & $11.8^{\mathrm{ab}}$ & $11.8^{\mathrm{ab}}$ & $11.9^{\mathrm{a}}$ & 0.14 & 0.100 & 0.038 & 0.197 & 0.503 \\
\hline$b^{*}$ & $17.3^{\mathrm{b}}$ & $17.7^{\mathrm{ab}}$ & $18.5^{\mathrm{a}}$ & $18.6^{\mathrm{a}}$ & 0.20 & 0.045 & 0.007 & 0.669 & 0.457 \\
\hline Chroma & $344.6^{\mathrm{b}}$ & $377.9^{\mathrm{ab}}$ & $389.7^{\mathrm{ab}}$ & $414.2^{\mathrm{a}}$ & 10.52 & 0.137 & 0.022 & 0.835 & 0.715 \\
\hline$h^{o}$ & 8.6 & 8.8 & 8.6 & 8.6 & 0.05 & 0.545 & 0.387 & 0.463 & 0.361 \\
\hline Haugh unit & 93.6 & 94.2 & 93.4 & 93.2 & 0.26 & 0.553 & 0.445 & 0.424 & 0.353 \\
\hline Breaking resistance $\left(\mathrm{kg} / \mathrm{cm}^{2}\right)$ & 1166.2 & 1056.9 & 1115.0 & 1118.2 & 23.10 & 0.421 & 0.676 & 0.224 & 0.283 \\
\hline
\end{tabular}

${ }^{\mathrm{a}-\mathrm{b}}$ Means in the same row bearing different superscripts differ significantly.

SED: Standard Error of the Difference between the means.

: Effects; L: linear, Q: quadratic, C: cubic.

\section{ACKNOWLEDGEMENTS}

The authors would like to thank Kırşehir Ahi Evran University, the Agricultural Faculty, the students of the Agricultural Biotechnology Department and also for the use of the University's construction material laboratory for the execution of this research.

\section{BIOETHICS AND \\ BIOSECURITY COMMITTEE APPROVAL}

The study followed an ethics document taken from the Animal Experiments Local Ethics Committee of Kırşehir Ahi Evran University dated and numbered 07/11/2018-21-2.

\section{DECLARATION OF CONFLICT OF INTERESTS}

The authors declare no conflict of interest. The founding sponsors had no role in the design of the study; in the collection, analyses, or interpretation of data; in the writing of the manuscript, and in the decision to publish the results.

\section{AUTHORS' CONTRIBUTIONS}

GF and AGF conceived and designed experiments. GF, AGF and AA performed the experiments, AGF carried out the lab analyses. GF supervised and coordinated the animal experiments and provided clinical data. GF performed statistical analyses of experimental data. GF and AGF prepared the draft of 
the manuscript. All authors critically revised the manuscript and approved of the final version.

\section{REFERENCES}

AL-HARTHI, M. A. et al. Effect of different dietary levels of mangrove (Laguncularia racemosa) leaves and spice supplementation on productive performance, egg quality, lipid metabolism and metabolic profiles in laying hens. British Poultry Science, v.50, n.6, p.700-708, 2009. Available from: <https:// www.tandfonline.com/doi/full/10.1080/00071660903202948>. Accessed: May, 28, 2020. doi: 10.1080/00071660903202948.

AOAC (Association of Official Analytical Chemists), 2006. Official Methods of Analysis. $18^{\text {th }} 437$ Washington, DC. AOAC. 2263.

CASTANON, J. I. R. History of the use of antibiotic as growth promoters in European poultry feeds. Poultry Science, v.86, n.11, p.2466-2471, 2007. Available from: <https://www.sciencedirect. com/science/article/pii/S0032579119390716>. Accessed: May, 28, 2020. doi: $10.3382 /$ ps.2007-00249.

CHOWDHURY, S. D.; SMITH, T. K. Effects of dietary garlic on cholesterol metabolism in laying hens. Poultry Science, v.81, n.12, p.1856-1862, 2002. Available from: <https://www.sciencedirect. com/science/article/pii/S0032579119438108> . Accessed: May, 28 , 2020. doi: $10.1093 / \mathrm{ps} / 81.12 .1856$.

COPUR, G. et al. Egg weight but not egg shape index, determines the hatchability in Japanase quail (Coturnix coturnix japonica). Journal of Animal and Veterinary Advances. v.9, n.13, p.18901895, 2010. Available from: <https://www.cabdirect.org/cabdirect/ abstract/20103288424>. Accessed: May, 28, 2020.

DÜZGÜNEŞ, O. et al. Araştırma ve deneme metodları (İstatistik Metodları-II). Ankara Üniversitesi Ziraat Fakültesi Yayınları, 1987, 1021.295, p.10-13.

EL-DEEK, A. A. et al. Hot pepper (Capsicum Annum) as an alternative to oxytetracycline in broiler diets and effects on productive traits, meat quality, immunological responses and plasma lipids. European Poultry Science, v.76, n.2, p.73-80, 2012. Available from: <https://www.european-poultry-science. com/Hot-pepper-span-classws-name-Capsicum-Annumspan-asan-alternative-to-oxytetracycline-in-broiler-diets-and-effects-onproductive-traits-meat-quality-immunological-response,QUIEPT QyMjA3NjUmTUlEPTE4MzY4MQ.html?UID=58BC472866F 6B420B11F4A07250205D5FBC94461DC3C562E >. Accessed: May, 28, 2020

HOLST, H. et al. The capsaicin cough reflex in patients with symptoms elicited by odorous chemicals. International Journal of Hygiene and Environmental Health. v.213, n.1, p.66-71, 2010. Available from: <https://www.sciencedirect.com/science/ article/abs/pii/S1438463909001035?via\%3Dihub>. Accessed: May, 28, 2020. doi: 10.1016/j.ijheh.2009.08.005.

ERDOST, H. et al. FSH and LH cells in the laying hens and cocks, fed with a diet containing red hot pepper. Journal of Food Agriculture and Environment. v.4, n.1, p.119, 2006. Available from: $<$ https://www.wflpublisher.com/Abstract/706 $>$. Accessed: May, 28, 2020. doi: 10.1234/4.2006.706.

GADDE, U. et al. Alternatives to antibiotics for maximizing growth performance and feed efficiency in poultry: a review.
Animal Health Research Reviews. v.18, n.1, p.26-45, 2017. Available from: $<$ https://www.cambridge.org/core/journals/ animal-health-research-reviews/article/alternatives-to-antibioticsfor-maximizing-growth-performance-and-feed-efficiency-inpoultry-a-review/834725E86141F209DDDE7BBA11A98635>. Accessed: May, 28, 2020. doi: 10.1017/S1466252316000207.

GUYOT, N. et al. Antibacterial activity of egg white: influence of physico-chemical conditions. In: Book of Abstracts. (69 supplement). 15. European Symposium on the Quality of Eggs and Egg Products. 21. European Symposium on the Quality of Poultry Meat, Bergamo, ITA, 2013-09-15-2013-09-19, 1-15 p. World's Poultry Science Association-Italian Branch, 2013.

FAOSTAT. Food and Agriculture Organization of the United Nations. The total egg production of all countries database. Available from: <http://www.fao.org/faostat/en/\#data/QL $>$. Accessed: May, 28, 2020.

LI, H. et al. Effect of red pepper (Capsicum frutescens) powder or red pepper pigment on the performance and egg yolk color of laying hens. Asian-Australasian Journal of Animal Sciences. v.25, n.11, p.1605-1610, 2012. Available from: <https://www.ncbi. nlm.nih.gov/pmc/articles/PMC4093037/>. Accessed: May, 28, 2020. doi: 10.5713/ajas.2012.12235.

MAOKA, T. et al. Cancer chemopreventive activity of carotenoids in the fruits of red paprika Capsicum annuum L. Cancer Letters. v.172, n.2, p.103-109, 2001. Available from: <https://www.sciencedirect.com/science/article/abs/pii/ S0304383501006358?via\%3Dihub>. Accessed: May, 28, 2020. doi: $10.1016 / \mathrm{S} 0304-3835(01) 00635-8$.

PUVAČA, N. et al. Black pepper (Piper nigrum L.) and hot red pepper (Capsicum annum L.) in broiler chicken nutrition. In: Proceedings of the International Symposium on Animal Science 2014. Faculty of Agriculture, Belgrade-Zemun (Serbia). p.249-256, 2014. Available from: <https://agris. fao.org/agris-search/search.do?recordID=RS2017000925>. Accessed: May, 28, 2020.

PUVAČA, N. et al. Effect of garlic, black pepper and hot red pepper on productive performances and blood lipid profile of broiler chickens. European Poultry Science. v.79, n.1-13. 2015. Available from: <https://www.european-poultry-science.com/ Effect-of-garlic-black-pepper-and-hot-red-pepper-on-productiveperformances-and-blood-lipid-profile-of-broiler-chickens, QUIEP TQ2MzA2NTAmTU1EPTE2MTAxNA.html?UID=81A56E2F78 1C63685ED32A6D0BC42A4CAD7CD69B8812A7>. Accessed: May, 28, 2020. doi: 10.1399/eps.2015.73.

SAS. SAS User's Guide: Statistics. 1997 Edit. SAS Institute, Inc., Carry, NC.

SHAHVERDI, A. et al. The effect of use red pepper (Capsicum annum L.) and black pepper (Piper nigrum L.) on performance and hematological parameters of broiler chicks. European Journal of Zoological Research. v.2, n.6, p.44-48, 2013. Available from: $<$ https://www.scholarsresearchlibrary.com/articles/the-effect-of-usered-pepper-capsicum-annum-1-and-black-pepper-pipernigrum-l-onperformance-and-hematological-parameters.pdf $>$. Accessed: May, 28, 2020.

RADWAN, N. L. et al. Effect of natural antioxidant on oxidative stability of eggs and productive and reproductive performance of laying hens. International Journal of Poultry Science. v.7, n.2, 
p.134-150, 2008. Available from: <http://www.docsdrive.com/ pdfs/ansinet/ijps/2008/134-150.pdf>. Accessed: May, 28, 2020.

TORKI, M. et al. Single and combined effects of zinc and cinnamon essential oil in diet on productive performance, egg quality traits, and blood parameters of laying hens reared under cold stress condition. International Journal of Biometeorology. v.59, n.9, p.1169-1177, 2015. Available from: <https://link.springer.com/ article/10.1007/s00484-014-0928-z>. Accessed: May, 28, 2020. doi: $10.1007 / \mathrm{s} 00484-014-0928-\mathrm{z}$.

USDA (United States Department of Agriculture), 2018. Agricultural Research Service, National Nutrient Database for
Standard Reference Legacy Release. National Nutrient Database for Standard Reference 1 Release April, 2018.

ŞENKÖYLÜ, N. Modern Tavuk Üretimi, 3. Baskı, Anadolu Matbaası, İstanbul, p.280-286, 2001.

ZEWEIL, H. et al. Effect of dried garlic and hot pepper as feed additives on the performance and egg quality of laying japanese quail hens. Conference: $\mathbf{X X}^{\text {th }}$ European Symposium on the Quality of Poultry Meat. b-042. Available from: $<$ https://www. researchgate.net/publication/223736446_Effect_of_dried_garlic_ and hot_pepper_as_feed_additives_on_the _performance_and_egg quality_of_laying_japanese_quail_hens $>$. Accessed: May, 28, 2020. 